\title{
Refah Devletine Yönelik Birey Tutumları: Refah Devleti Politikaları Türkiye'de Sosyal Sermayeyi Etkiler mi?*
}

\section{Individual Attitudes Toward the Welfare State: Do the Welfare State Policies Affect Social Capital in Turkey?}

\author{
Durmuş Ali Yüksek, ${ }^{\mathrm{a}}$ \\ ${ }^{\text {a }}$ Dr., Kara Harp Okulu, Ankara, Türkiye \\ durmusaliyuksek@gmail.com \\ ORCID: 0000-0002-1153-7853
}

\section{MAKALE BİLGÍSI}

\section{Makale Geçmişi:}

Başvuru Tarihi: 10.03. 2020

Düzeltme Tarihi: 28.12.2020

Kabul Tarihi: 29.12.2020

Anahtar Kelimeler:

Refah Devleti,

Sosyal Sermaye

Güven

Dışlama

Pekiştirme

\begin{abstract}
ÖZ
Geçmişte yapılan birçok araştırmada refah devleti ve sosyal sermaye arasındaki ilişki incelenmiş ve birbiriyle çelişen sonuçlar bulunmuştur. $\mathrm{Bu}$ araştırmaların bir kısmı, refah devletinin mevcut uygulamaları vasıtasıyla sivil toplumu gereksiz kıldığını ve sosyal sermaye üretimini zorlaştırdığını belirtirken, diğer bir kısmı ise, refah devletinin sosyal sermaye üzerinde olumlu ve canlandırıcı bir etkisinin olduğunu ortaya koymuştur. Ancak, bu çalışmaların neredeyse tamamı 1970'ler sonrasından başlayarak Avrupa ülkelerine odaklanmıştır ve Türkiye'yi kapsamına alan bir çalışma literatürde bulunmamaktadır. Bu nedenle, mevcut çalışmanın amacı, bu eksikliği ortadan kaldırmak ve Türkiye'deki refah devleti politikalarının bireyler arasındaki sosyal sermaye (güven) oluşumunu olumlu veya olumsuz ne şekilde etkilediğini ortaya koyabilmektir. Bunun için, Avrupa refah devletlerine odaklanan bir çalışma model olarak alınmış, bu model çalışma doğrultusunda ilişkisel araştırma yöntemi kullanılarak Türkiye'nin de dahil olduğu analizler yapılmış ve refah devleti ile sosyal sermaye arasındaki ilişki Türkiye odaklı incelenmiş̧ir. Çalışma sonucunda, Türkiye'de refah devleti politikalarına yönelik oluşan birey tutumlarının sosyal sermayeye etkisi üzerine değerlendirmelerde bulunulmuştur.
\end{abstract}

\section{ARTICLE INFO}

\section{Article History:}

Received: 10.03.2020

Received in revised form: 28.12.2020

Accepted: 29.12.2020

Keywords:

Welfare State

Social Capital

Trust

Crowding Out

Reinforcement

\begin{abstract}
Past research has addressed the relationship between the welfare state and social capital and found contradictory results. Some argue that strong welfare states make civil society unnecessary, making the production of social capital more difficult. Others think otherwise and argue that welfare state has a positive and stimulating effect on social capital. However, almost all these studies, which have been conducted since 1970s, have focused on European countries, and there are no studies addressing the same relationship in the literature, focusing on Turkey. The aim of this study, therefore, is to fill this research gap and reveal to what extent and how the welfare state policies in Turkey affect the formation of social capital (interpersonal trust) among individuals, either positively or negatively. To do this, a model study that focuses on European welfare states was employed to conduct analyses on Turkey using a relational research method, and thus the relationship between the welfare state and social capital in Turkey was examined. In conclusion, evaluations were made regarding the effect of individual attitudes toward welfare state policies on social capital in Turkey.
\end{abstract}

\section{Atıf Bilgisi / Reference Information}

Yüksek D. A. (2020). Refah Devletine Yönelik Birey Tutumları: Refah Devleti Politikaları Türkiye'de Sosyal Sermayeyi Etkiler mi? Uluslararası Kültürel ve Sosyal Araştırmalar Dergisi (UKSAD), 6 (2), Kış, s. 789-807. 


\section{Giriş}

Refah devleti, devlet gücünün kasıtlı olarak bireylere ve ailelere asgari bir gelir garantisi verebilmek, bireylerin ve ailelerin ihtiyaçlarının karşılanmasını sağlayarak güvensizliğin kapsamını daraltabilmek ve statü veya sınıf ayrımı olmaksızın bütün vatandaşlara en iyi sosyal hizmeti sunabilmek amacını benimseyen devlet anlayışını ifade etmektedir (Briggs, 1961). Refah devleti uygulamalarının başarısı, toplumları daha yaşanılır, eşit ve demokratik kılmasına bağlıdır. Bu kapsamda, araştırmacıların, refah devleti, bireylerin refah devletine yönelik tutumları ve bu tutumların ülkeler arasında ne şekilde değişmekte olduğu konusu üzerine artan ilgilerinin makul olduğunu değerlendirmek mümkündür.

Refah devletine yönelik artan ilgi, araştırmacıları, refah devletinin sosyal bilimlerde son yılların bir diğer popüler araştırma konusu olan sosyal sermaye üzerine olan etkisini de incelemeye yöneltmiştir. Sosyal sermaye, bireyler arası ilişkileri, yani sosyal ağlar ile bu ağlardan kaynaklanan karşılıklılık ve güvenilirlik normlarını işaret eder (Putnam, 2000). Sosyal sermaye kavramındaki temel düşünce, bireyin sahip olduğu güçlü (örn. aile ve arkadaş) ve zayıf (örn. tanıdıklar) bağların bireye hem maddi hem de manevi faydalar sağlayabilecek bir değer oluşturmasıdır. Bu bağlamda, refah devleti ve sosyal sermaye arasındaki ilişkiyi inceleyen bir kısım araştırmacılar, refah devletinin sivil toplumu etkisizleştirerek bireylerin sosyalleşmeleri üzerine olumsuz bir etki yarattığını ve bunun da sosyal sermayenin oluşumunu engellediğini ortaya koymuşlar (Wolfe, 1989; Etzioni, 1995; Fukuyama, 2001; Scheepers, Te Grotenhuis ve Gelissen, 2002) ve bunu da refah devletinin sosyal sermayeyi "dışlaması" (dışlama hipotezicrowding out hypothesis) (van Oorschot ve Arts, 2005) olarak adlandırmışlardır. Diğer bir kısım araştırmacı ise, bu bulguların tam tersini tespit etmiş ve refah devletinin aslında bireylerin birbirlerine karşı olan sorumluluklarını devraldığını ve bunun da insanların mevcut zaman, enerji ve maddi imkanlarını sosyalleşme çabalarına yöneltmelerine yardımcı olduğunu ve sonuç olarak da refah devletinin sosyal sermayeyi “pekiştirdiğini”" (pekiştirme hipotezi-reinforcement hypothesis) ve sosyal ilişkilerin ve sosyal sermayenin artmasına sebep olduğunu iddia etmişlerdir (van Oorschot ve Arts, 2005; van Oorschot, Arts ve Halman, 2005; Kaariainen ve Lehtonen, 2006; Stadelmann-Steffen, 2011; Rostila, 2013).

Refah devleti kavramı, özellikle Gosta Esping-Andersen'in (1990) refah devletlerini gruplandırdığg ve bu gruplamalara yönelik değerlendirmelerde bulunduğu "Three Worlds of Welfare Capitalism" adlı öncü çalışmasından sonra popülerlik kazanmış ve bu çalışmayı örnek alan, destekleyen veya eleştiren birçok çalışma yapılmıştır. Literatürde refah devleti kavramı üzerine Türkiye odaklı birçok çalışma bulunsa da (Özdemir, 2005; Alp, 2009; Elveren ve Elveren, 2010; Taşç1, 2013; Tiyek ve Yertüm, 2016), refah devleti ve sosyal sermaye ilişkisini ve refah devletinin sosyal sermayeyi dışlaması veya pekiştirmesi hipotezlerini ele alan çalışmaların neredeyse tamamının Avrupa ülkelerini esas aldığını ifade etmek mümkündür. $\mathrm{Bu}$ kapsamda, Türkiye'de refah devletinin durumu ve refah politikalarının sosyal sermayeye etkisi üzerine yapılmış herhangi bir çalışma bulunmamaktadır. Mevcut çalışma, bu eksiği kapatmayı ve literatüre önemli bir katkı sağlamayı amaçlamaktadır.

Literatürdeki bu eksiği kapatmak maksadıyla, Yuksek ve Solakoglu'nun (2019) Avrupa refah devletlerindeki refah devleti politikaları ve sosyal sermaye ilişkisini inceledikleri çalışma model alınmıştır. Bu çalışmanın model alınmasının sebebi, söz konusu çalışmada Türkiye özelinde değerlendirmelerde bulunulmamış olmasına rağmen, kullanılan veri setinin Türkiye'ye yönelik verileri de içeriyor olmasıdır. Böylece, mevcut çalışmada, model çalışmanın refah devleti ve sosyal sermaye ilişkisini ele alış şekli model alınarak ve ilişkisel araştırma yöntemi kullanılarak Türkiye’ye yönelik veriler analiz edilmeye ve bu veriler doğrultusunda Türkiye'ye yönelik değerlendirmelerde bulunulmaya çalışılmıştır.

Bu bağlamda, çalışmanın ikinci kısmında refah devleti ve sosyal sermaye ilişkisinin temelini oluşturan "dışlama" ve "pekiştirme" hipotezleri tartışılacak ve bu hipotezleri konu alan çalışmaların sonuçları 
değerlendirilecektir. Üçüncü kısımda, literatürde kabul gören refah rejimleri hakkında bilgi sunulacak ve Türkiye'nin de içinde bulunduğu "Akdeniz" refah rejimi detaylı incelenecektir. Dördüncü kısımda, bu çalışmanın temelini oluşturan ve çalışmaya model olan Yuksek ve Solakoglu'nun (2019) çalışmasının bulguları ortaya konacaktır. Son olarak, beşinci kısımda da model çalışmanın esasları üzerinden Türkiye odaklı değerlendirmelerde bulunulacak ve çalışma sonlandırılacaktır.

\section{Refah Devleti ve Sosyal Sermaye İlişkisi: "Dışlama” ve "Pekiştirme” Hipotezleri}

Son yıllarda, sosyal sermaye kavramı, sosyolojik teoriden günlük dile yapılan en önemli katkılardan (Portes, 1998) ve sosyal araştırmaların en popüler araştırma konularından birisi haline gelmiştir. Toplumsal yaşamın her alanına bakan yönü, sosyal sermayenin bu popülerliği kazanmasının en önemli sebeplerindendir. Sosyal sermaye, temelde bireye maddi ve manevi faydalar sağlayan sosyal ilişkiler ağını temsil ediyor olsa da bu kavramın çok yönlü bir niteliği vardır. Sabatini'nin (2009) de belirttiği gibi, bu çok yönlülük, sosyal sermayenin tek bir kavramla özdeşleştirilmesini engeller. Buna karşın, sosyoloji literatüründe, güvenin sosyal sermayenin temel bir bileşeni ve aynı zamanda temel bir göstergesi, bazen de en belirgin ve tek göstergesi olduğu ifade edilmektedir (Delhey ve Newton 2003). Bu bağlamda, birçok araştırmacı güveni sosyal sermaye ile ilişkilendirmiş (Putnam, 2000; Fukuyama, 2001; Knack ve Kiefer, 1997; Yuksek, 2017) ve birbirine güvenen bireylerin hem daha mutlu ve sağlıklı olduklarını (Rostila, 2013) hem de daha erdemli vatandaşlar haline geldiklerini ifade etmişlerdir (Putnam, 2000). Sosyal sermaye göstergesi olarak güven, aynı zamanda, insanların sosyal sorunlara çözüm sağlamak için örgütlendiği bir sivil toplumun verimliliğinin de göstergesi haline gelmiştir.

Fukuyama'ya (1995) göre, bir bireyin sosyalleşmesi üç yolla meydana gelebilir. Bunlar, aile, aile dışındaki gönüllülük esasına göre faaliyet gösteren okul, sosyal kulüp veya profesyonel örgütlenmeler gibi kurumlar ve son olarak devlettir. Bunlardan ilki olan ailede, doğumunu müteakip birey iletişim kurma ve sosyalleşme becerilerini kazanır. Ancak, esas itibariyle sosyalleşme becerilerini geliştirme süreci aile dışında, etkin bir sivil toplumda gerçekleştirilir. Çünkü, sivil toplum, farklı özelliklere sahip bireylerin bir araya gelebilmesine, ortak değerler etrafında birleşerek ortak bir irade oluşturmalarına, bu ortak irade ile kolektif hareket etmelerine ve sonuç olarak da önce sivil toplumun varlığı dolayısıyla yakınlaşarak ortak bir irade geliştirdikleri yabancılara ve sonrasında da toplumun geneline karşı güven duygusu geliştirmelerine sebep olur. Diğer bir deyişle, bireyler aktif ve etkin bir sivil toplumda, ortak değerler etrafında buluştukları diğer bireylerle beraber kaynaşarak toplumun geneline yönelik olarak güven duymaya başlarlar.

Eğer bireylerin diğer bireylerle ortak bir zemin geliştirebilecekleri aktif bir sivil toplum mevcut değilse ya da bireyler kendi başlarına sivil toplumu aktif olarak kullanamıyorlarsa, bu durumda devletler bireylerin organize olarak başaramadıkları hususlara el atarak bu hususları onların yerine gerçekleştirmeye çalsşabilirler. Ancak, bu durumda, devlet müdahalesinin nerede durması gerektiği sorusu ortaya çıkacaktır (Fukuyama, 1995). Tam da bu aşamada "dişlama" hipotezi (van Oorschot ve Arts, 2005) refah devletlerinde devlet müdahalesinin sosyal sermaye üzerine olan etkisine 1 şı tutabilecek bir yöntem olarak ortaya çıkmaktadır.

Dışlama hipotezini konu alan çalışmalar iki zıt argümanı (hipotezi) göz önünde bulundurmuşlardır. Bunlardan ilkinde (dışlama hipotezi), refah devleti uygulamaları bireylerin sorumluluklarını azalttığı için, bireyler diğer bireylerle daha az iletişim ve etkileşim kurmakta, bu da sivil toplumu gereksiz hale getirmektedir. Yani, refah devleti, politikaları vasıtasıyla sivil toplumu, toplumsal ilişkileri, güveni ve dolayısıyla sosyal sermayeyi dışlamaktadır (Fukuyama, 2001; Rostila, 2013). Örneğin, Scheepers vd. (2002), evrensel ve kapsayıcı refah devletlerinde sosyal sermaye seviyesinin diğer devletlere göre düşük olduğunu tespit etmiş ve dişlama hipotezini destekleyecek sonuçlar bulmuştur. 
Diğer argümanı (pekiştirme hipotezi) destekleyen çalışmalar ise, tam tersine refah devleti uygulamalarının bireylerin sorumluluklarını azaltarak onların mevcut zaman, enerji ve maddi imkanlarını diğer bireylerle iletişim kurarak ve iş birliği yaparak geçirebilecekleri fikri üzerine inşa edilmiştir. Bu kapsamda, refah devleti, uyguladığı politikalarla sivil toplumu, toplumsal ilişkileri, güveni ve dolayısıyla sosyal sermayeyi pekiştirmekte yani güçlendirmektedir. Örneğin, yapılan çalışmalarda, araştırmacılar, dışlama hipotezinin doğruluğunu kanıtlayamamış ve evrensel refah devletlerinin ve güçlü refah devleti uygulamalarının sosyal sermayeyi artırdığını tespit etmişlerdir (van Oorschot ve Arts, 2005; Kaariainen ve Lehtonen, 2006; Rostila, 2013).

Bir refah devletinin sivil toplum vasıtasıyla bireylerin sosyal faaliyetlere aktif katılımını ve güveni, yani sosyal sermayeyi pekiştirdiği duruma dolaylı pekiştirme (indirect reinforcement) adı verilebilir. Çünkü, refah devleti sivil toplumu etkilerken, sivil toplum da toplumsal faaliyetlere aktif katılımı ve güveni etkilemekte, böylece dolaylı bir pekiştirme sağlanmaktadır.

Bunun yanı sıra, refah devletleri politikaları vasıtasıyla güveni dolaysız ve direkt bir şekilde de etkileyebilmekte ve sosyal sermayeyi pekiştirebilmektedir (direct reinforcement). Bu durumu şu şekilde açıklamak mümkündür. Gelir dağılımındaki farklılıklar veya gelir eşitsizliği ile toplumun heterojenliği (community heterogeneity), yani farklı sınıftan, dinden, ırktan, etnik gruptan veya cinsiyetten insanların bir arada bulunması güven duygusu ile yakından ilişkilidir. İnsanlar kendilerine daha yakın ve eşit gördükleri (kendilerine benzer özellikteki) kişilere karşı güven duyma eğilimindedirler (Stolle, 2003). Öte yandan, gelir dağılımındaki eşitsizlikler, insanları birbirinden uzaklaştırmakta ve onlara birbirleriyle ortak bir değere sahip olmadıkları hissini vermektedir. Aksine, kaynaklar eşit bir şekilde dağıtılabilse ve gelir eşitsizliğinin yarattığı olumsuzluklar bir nebze de olsa azaltılabilse, insanların ortak bir değere tutunabilme ihtimali artacaktır (Uslaner, 2002). Bu kapsamda, refah devleti etkin politikalarla ve kapsayıcı programlarla yoksulluğu ve işsizliği ortadan kaldırabilecek, daha eşit bir kaynak dağılımı yaratabilecek, toplumsal bütünlüğe zarar veren sosyal ayrılık sebeplerini azaltabilecek ve sonuçta insanların birbirlerine güven duymalarını sağlayabilecek bir güce sahiptir (Esping-Andersen, 1990). Yani, refah devletleri bireylerin birbirlerine karşı besledikleri güven duygusunu artırarak sosyal sermayeyi dolaysız yoldan ve direkt olarak pekiştirebilir.

Refah devletleri, politikaları vasıtasıyla sosyal sermayeyi (güveni) pekiştirirken, bunun tam zıttı da mümkündür. Yani, refah devletleri politikaları vasıtasıyla güvensizliği de pekiştirebilmekte ve sosyal sermayeye zarar verebilmektedir. Refah devletleri bireylerin ihtiyaçlarına yönelik olarak duyarlı, güvenilir, eşit ve tarafsız davranarak bireylerin meşru iradeye saygı ve güven duymalarını sağlayabilirler (Tyler, 2006). Toplumdaki tüm bireylerin de bu şekilde düşünecekleri varsayılırsa, meşru iradeye karş1 geliştirilen güven toplumun geneline de yansıyacaktır. Aynı şekilde, bireyler refah devletlerinde politikaları geliştiren ve uygulayan devlet görevlilerinin tavır ve davranışlarından da etkilenmekte ve onlarla yaşadıkları deneyimleri genele yansıtmaktadırlar. Yani, eğer bireyler devlet görevlileri ile olan etkileşimlerinde dürüstçe, eşit ve tarafsız bir muamele ile karşılaşmış ve iyi bir deneyim yaşamışlarsa, kendilerini daha güvende hisseder ve bu deneyimleri doğrultusunda kendilerini diğer bireylere güven duymaya teşvik edebilirler. Ancak, tam tersi olmuşsa, refah devletleri bireylerin ihtiyaçlarına karşı duyarsız, adaletsiz ve taraflı davranmışsa ve bireyler devlet görevlileri ile olan etkileşimlerinde duyarsız, saygısız ve adaletsiz bir muamele ile karşılaşmış ve kötü bir deneyim yaşamışlarsa, refah devleti politikaları ve devlet görevlileriyle yaşadıkları bu kötü deneyimleri genele yansıtır ve nasıl refah devletine, devlet politikalarına ve devlet görevlilerine güvenmiyorlarsa, diğer insanlara da güvenmemeye başlarlar (Stolle, 2003; Rothstein ve Stolle, 2003). Bu durumda ise, refah devleti güvensizliği pekiştirmiş ve sosyal sermayeyi olumsuz etkilemiş olur. 


\section{Refah Rejimi Türleri}

Avrupa ülkelerinde sosyal sermayenin ülkeden ülkeye farklılaşıp farklılaşmadığını tespit etmek ve refah devletlerinin politikaları vasıtasıyla sosyal sermayeyi "dışladığını" ya da "pekiştirdiğini” anlayabilmek için öncelikle Avrupa ülkelerinin ve elbette Türkiye'nin refah rejimleri açısından ne şekilde farklılaştı̆̆ının üzerinde durulmalıdır.

Esping-Andersen, refah rejimlerini, devlet, ekonomi ve ev halkı arasındaki ilişkileri düzenleyen ve tarihsel bir gelişim sürecinde ortaya çıkan ve evrilen, sistematik, yasal ve örgütsel işlevler bütünü olarak ifade eder (Kaariainen ve Lehtonen, 2006). Bahsi geçen düzenlemeler sayesinde refah devletleri bireyin yaşam süresince karşılaşabileceği problemlere ve risklere karşı politikalar geliştirir.

Esping-Andersen (1990), ülkeleri üç farklı refah rejimine göre sınıflandırmıştır. Bu sınıflandırmayı da piyasanın, ailenin ve devletin refahı sağlama konusundaki rollerinin ülkeden ülkeye ne şekilde değişmekte olduğunu inceleyerek yapmıştır. İncelemeleri sonucunda ortaya koyduğu refah rejimi türleri "liberal," "muhafazakâr" ve "sosyal demokrat" refah rejimleridir.

“Anglo-Saxon” ülkelerinde yaygın olarak görülen liberal rejimde, devletin vatandaşlarına sağladığı yararlar asgari düzeydedir ve bu yararlardan faydalanma genellikle varlık araştırmasına (means-testing) bağlıdır. Yapılacak yardımların varlık araştırmasına dayalı olması, bu sistemde ihtiyaç durumunda bulunanların damgalanmasına neden olmaktadır. Bu sebeple de liberal rejimin genel ve kapsayıcı bir yapısı yoktur ve devlet her türlü yol denendikten sonra başvurulacak en son merci olarak görülmektedir. İngiltere, Amerika Birleşik Devletleri, İrlanda, Avusturalya ve Yeni Zelanda bu tür bir refah rejimine sahiptir (Özdemir, 2005).

Genellikle Orta Avrupa ülkelerinde yaygın olarak görülen muhafazakâr rejim tipinde, devlet refah yardımları için büyük oranda destek sağlar. Evrensel bir sistem yerine, sigorta sistemi ve varlık araştırmasına dayalıdır. Sigorta sistemi sebebiyle çalışanlara piyasa risklerinden sistematik olarak korunmayı getirse dahi, emek piyasasıyla doğrudan ve sağlam bağlantıları olmayan bireyleri koruma konusunda yetersizdir. Avusturya, Fransa, Almanya, İtalya ve Belçika bu türe uygun düşecek refah sistemlerine sahiptir (Özdemir, 2005).

İskandinav ülkeleri ile Danimarka ve Hollanda'da görülen sosyal demokrat rejim türünde öne çıkan ilkeler ise, evrensellik, sosyal dayanışma ve sınıflar arası eşitliktir. $\mathrm{Bu}$ rejim türünde minimum gereksinimlerin karşılanmasına dayalı bir eşitlikten ziyade, gereksinimlerin yüksek düzeyde karşılanması ile oluşacak eşitliği hedefleyen bir refah devleti anlayışı hakimdir (Özdemir, 2005).

Esping-Andersen'in üçlü tipolojisine ek olarak, Kaariainen ve Lehtonen (2006) iki farklı türde refah rejimi daha olduğunu öne sürmüşler ve bu türleri "sosyalist sonrası" ve "Akdeniz" refah rejimleri olarak adlandırmışlardır. Sosyalist sonrası refah rejimi, genel olarak Doğu Avrupa ülkelerini kapsamakta, yüksek seviyede sosyal güvenlik kapsamı ve düşük seviyede sosyal güvenlik getirileriyle tanımlanmaktadır. $\mathrm{Bu}$ sebeple, bu rejim türünde insanlar büyük oranda aile desteğine ihtiyaç duymaktadırlar (Rostila, 2013).

Akdeniz refah rejimi ise, Stephan Leibfried'in “Latin Kuşağı Ülkeleri” (Latin Rim) olarak adlandırdığı ülkeleri kapsamaktadır. Bu rejim türünde, vatandaşlara sağlanan sosyal olanaklar çok yetersizdir. Ancak, bu refah rejimini benimsemiş ülkelerin anayasa ve ilgili yasalarına bakıldığında, modern bir refah devletinde olması gereken bütün kurumsal gelişmelerin vaat edilmiş olduğu görülmektedir. Bu rejim türünde sosyal güvenlik ve daha genel anlamda sosyal koruma sisteminin yetersizliği enformel bağlar ve aile/arkadaşlık bağları ile ortadan kaldırılmaya çalışılmaktadır (Özdemir, 2005). 
Türkiye'nin durumu ele alındığında, Kuzey Avrupa ülkelerine göre kurumsallaşma aşamasında olan sosyal koruma uygulamaları (2008 yılında Genel Sağlık Sigortası sistemine geçiş ile başlanmıştır) ve din ve aileye dayalı gönüllü sosyal koruma uygulamalarının varlığı temel özelliklerindendir. Bunun yanında, Genel Sağlık Sigortası ilk bakışta her bireye ayrım yapılmaksızın bir vatandaşlık hakkı olarak sunulmuş olsa da, bu sigortadan daha fazla kişiyi faydalandırma çabası sigortanın kapsamını daraltmış ve sağlık hizmetlerinin tam anlamıyla metalaştırılması sürecini başlatmıştır (Elveren ve Elveren, 2010). Aile neredeyse tek başına hemen hemen tüm sorunlarda (işsizlik, yoksulluk, sosyal dışlanma, yaşlı, çocuk ve engellilerin korunması) devletin sosyal politika alanındaki yükünü hafifletir haldedir (Taşçı, 2013). Ancak, aileyle ilgili Türkiye'de gözlenen bir husus ise, geniş ailenin, bireylerini destekleyecek yeterli finansal güce artık sahip olmadığı ve geniş ailenin yerini çekirdek ailenin almakta olduğudur. Yani, ailenin sosyal koruma rolü önemli ölçüde zayıflamaktadır (Elveren ve Elveren, 2010). Geç sanayileşmiş olması, buna bağlı olarak sosyal korumayı prim esasına dayandırmış olması, işgücü ve istihdam yapısı, işgücünün cinsiyete göre dağılımı ve gelir dağılımı gibi unsurlar ele alındığında, Türkiye’nin GüneyKuzey ayrımında Güney Avrupa ülkeleriyle benzeşmekte olduğu görülmektedir. (Tiyek ve Yertüm, 2016). Bu sebeple de Türkiye'nin belirtilen beş refah rejimi arasından en çok Akdeniz refah rejiminin özelliklerini barındırdığını ifade etmek mümkündür (Tiyek ve Yertüm, 2016).

Yukarıda izah edilen beş farklı türdeki refah rejimleri (Esping-Andersen'in üçlü tipolojisi ve buna ek olarak Kaariainen ve Lehtonen'in öne sürdüğü iki refah rejimi türü), sağlamış oldukları emekli maaşı, sağlık hizmetleri, sağlık sigortası, çocuk bakımı, çocuk yardımı, eğitim imkanları ve işsizlik sigortası gibi refah programlarının evrenselliği veya seçiciliği bakımından farklılaşmaktadır. Bu farklılaşma özellikle refah devleti uygulamaları ile sosyal sermaye arasındaki ilişki açısından büyük önem arz etmektedir. Evrensel bir refah programının temel prensibi, sadece ihtiyacı olanın değil bütün herkesin bu programdan faydalanması ve bireylere sınıf, ırk veya cinsiyet farkı gözetmeksizin eşit olarak davranılmasıdır. Bu da evrensel bir refah programında bürokratik takdir yetkisine ve varlık araştırmasına yer olmadığı anlamına gelir (Rothstein, 1998). Diğer yandan, seçici refah programları ise, sadece varlık araştırmasını başarıyla geçen bireylere sunulur. Bu da seçici programlardan faydalanmak için bireylerin belli gereksinimleri ve şartları sağlamaları gerektiği anlamına gelir (Kumlin ve Rothstein, 2005). Bu sebeple, seçici refah programları, bireyleri, sunulan imkanlardan faydalanmak için sistemi kandırmaya ya da ilgililere rüşvet vermeye teşvik edebilir. Sonuç olarak, sosyal demokrat refah rejimlerinin evrensel ve oldukça cömert imkanlar sunan rejimler olduklarını, muhafazakâr ve bir ölçüde de Akdeniz refah rejimlerinin cömert imkanlar sunan ancak seçici rejimler olduklarını ve son olarak liberal ve sosyalist sonrası refah rejimlerinin de ne cömert imkanlar sunabilen ne de evrensel olan rejimler olduklarını ifade etmek mümkündür (Esping-Andersen, 1990).

\section{Model Çalışma}

$\mathrm{Bu}$ kısımda, teorik çerçevesi oluşturulan dışlama ve pekiştirme hipotezlerinin, refah rejimlerinin özellikleri de göz önünde bulundurulduğunda Avrupa ülkelerinde ne şekilde desteklenip desteklenmediğini ortaya koymak ve Türkiye üzerine bazı değerlendirmelerde bulunmak maksadıyla Yuksek ve Solakoglu'nun (2019) 25 Avrupa ülkesini kapsayan çalışması model alınacaktır. ${ }^{1}$ Yuksek ve Solakoglu, çalışmalarında Avrupa ülkelerini genel olarak karşılaştırmış ve herhangi bir ülke özelinde değerlendirmede bulunmamıştır. Bu sebeple, Türkiye özelinde değerlendirmelerde bulunmadan önce Yuksek ve Solakoglu'nun (2019) çalışmasının ana hatlarından bahsedilecek ve sonrasında bulgularının Türkiye özelinde değerlendirmesi yapılacaktır.

\footnotetext{
${ }^{1}$ Esping-Andersen (1990), Arts ve Gelissen (2002) ve Rostila'nın (2013) araştırmalarını esas aldıkları çalışmalarında, Yuksek ve Solakoglu (2019), çalışmalarına dahil ettikleri 25 Avrupa ülkesini refah rejimleri açısından şu şekilde gruplandırmışlardır: Danimarka, Finlandiya, Hollanda, Norveç ve İsveç (Sosyal Demokrat), İrlanda ve Birleşik Krallık (Liberal), Belçika, Fransa, Almanya ve İsviçre (Muhafazakar), Yunanistan, İsrail, Portekiz, İspanya ve Türkiye (Akdeniz), Hırvatistan, Çek Cumhuriyeti, Macaristan, Litvanya, Polonya, Romanya, Rusya, Slovenya ve Ukrayna (Sosyalist Sonrası).
} 
Yuksek ve Solakoglu (2019), sosyal sermayenin Avrupa'nın farklı ülkelerinde sistematik bir şekilde farklılaşıp farklılaşmadığını, refah devletlerinin sosyal sermayenin varlığını etkileyip etkilemediğini ve hangi durumlarda refah devletinin sosyal sermayeyi dışladığını, hangi durumlarda ise pekiştirdiğini inceledikleri çalışmalarını, 2008 yılı Avrupa Sosyal Anketi’ni (European Social Survey) kullanarak ve 25 Avrupa ülkesinden 37984 kişinin bilgilerini analiz ederek yapmışlardır. Çalışmalarında, sosyal sermayeyi, literatürde de sosyal sermayenin temel göstergelerinden biri olan güven (Delhey ve Newton, 2003) ile ilişkilendirmişlerdir. Çünkü, Newton'un (2001) da belirttiği gibi, güven, insanların başkalarıyla daha barışçıl ve istikrarlı ilişkiler kurmasını sağladığı için toplumsal yaşamın temel bir bileşenidir ve bu da kolektif davranış ve üretken iş birliğinin temelini oluşturur. Bireylerin diğer bireylere karşı beslemiş oldukları güveni de, Avrupa Sosyal Anketi ve Dünya Değerler Anketi (World Values Survey) gibi kapsamlı birçok ankette güveni ölçmek için kullanılan standart bir soru ile ölçmüşlerdir: "Size göre, genel olarak, çoğu insana güvenilebilir mi, yoksa insanlarla muhatap olurken çok dikkatli olmak mı gerekir?" Bu soruya verdikleri cevaplar ile bireyler 0'dan (insanlarla muhatap olurken çok dikkatli olmak gerekir) 10'a (çoğu insana güvenilebilir) kadar diğer bireylere karşı duydukları güvene ya da başka bir deyişle başkalarının güvenilirliklerine karar vermiş olurlar. Bu soru, Knack ve Keefer (1997) ve Uslaner'in (2002) de belirttiği üzere, soruluş biçimi itibariyle daha önceden tanıdığımız ve bildiğimiz kişilerden (particularized trust) ziyade hiç tanımadığımız yabancılara karşı beslemiş olduğumuz güveni (generalized trust) ölçmektedir.

Yuksek ve Solakoglu (2019) çalışmalarında, refah devletinin sosyal sermaye yani güven üzerindeki etkisini ölçmek maksadıyla refah devleti politikalarına yönelik oluşan birey tutumlarını incelemişlerdir. Tutum oluşumunun bireyin bazı ihtiyaçlarının uyarılmasına bağlı olduğu (Katz, 1960); yani bireylerin, ihtiyaçlarının giderilmesini sağlayan nesnelere, sosyal meselelere (örn., nükleer enerji, çevrenin korunması), çeşitli durumlara veya diğer bireylere (örn., politikacılar) karşı olumlu tutumlar geliştirme eğiliminde oldukları, bunun aksine ihtiyaçlarının giderilmesini engelleyenlere karşı ise olumsuz tutumlar geliştirme eğiliminde oldukları düşüncesinden hareketle, bireylerin refah devleti ile yaşamış oldukları deneyimler sonucu çeşitli isteklerinin ve ihtiyaçlarının karşılanıp karşılanmamasına bağlı olarak refah devletine yönelik tutumlar geliştireceklerini ifade etmişlerdir. Sonuç olarak, bireylerin, refah devletinin gücüne (refah devletinin etkisinin sınırlı ya da kapsamlı olması), refah devleti politikalarının sonuçlarına (deneyimlenen politikaların olumlu ya da olumsuz olarak algılanması) ve refah devleti politikaları ile politikaları uygulayan devlet görevlilerinin meşruiyetine (politikaların bireylere eşit faydalandırılıp faydalandırılmadığı ve politika uygulayıcıların bireylere eşit ve tarafsız davranıp davranmadığı) yönelik deneyimlerinin, refah devletine yönelik olumlu ya da olumsuz tutumlar geliştirmelerine sebep olabileceğini ifade etmişlerdir (Yuksek ve Solakoglu, 2019).

Ayrıca, Yuksek ve Solakoglu (2019) çalışmalarında, refah devletinin güven üzerine olan etkisinin Avrupa ülkelerinde ne şekilde farklılaştığını ortaya koymak ve bu farklılaşma sonucu dışlama ve pekiştirme hipotezlerine yönelik çıkarımlarda bulunmak maksadıyla da ülke serveti (a nation's level of wealth) ve ülke demokrasi kalitesini (quality of democracy) ülke değişkenleri olarak kullanmışlardır. Buradaki amaç, bir bireyin belirli varlıklara yönelik olarak geliştirmiş olduğu gerçek tutumlarının incelenebilmesinin ancak tutum gelişiminin gerçekleştiği bağlamın da (context) göz önünde bulundurulmasına bağlı olduğu görüşüdür (Eagly ve Chaiken, 2005). Son olarak, ülke seviyesi değişkenlerinin (country level - level 2) birey seviyesi değişkenlerini (refah devletine yönelik birey tutumlarını) (individual level - level 1) etkileyerek sosyal sermayeyi yani güveni ne şekilde artırdığını veya azalttığını belirlemek amacıyla da seviyeler arası etkileşimler yapmış (cross-level interactions) ve böylece güvenin ülke seviyesi değişkenleri ve birey seviyesi değişkenlerine bağlı olarak Avrupa ülkelerinde farklılaşıp farklılaşmadığını ortaya koymuşlardır. 


\section{Türkiye'de Refah Devleti ve Sosyal Sermaye İlişkisi}

Yuksek ve Solakoglu'nun (2019) çalışmasının ana hatlarını açıkladıktan sonra bu kısımda çalışmanın bulgularının Türkiye açısından ne anlama geldiği üzerinde durulacaktır. Öncelikle, Tablo 1'de, 2008 yılında refah rejimleri açısından çalışmaya dahil edilen 25 ülkenin ortalama güven, ülke serveti ve ülke demokrasi kalite puanları gösterilmiştir. Tablo 1 incelendiğinde görüleceği üzere, 2008 yılında Türkiye açık ara en düşük ortalama güven puanına (2.18), Ukrayna, Romanya ve Rusya'dan sonra en düşük ülke servetine $(9770 \$)^{2}$ ve Rusya'dan sonra en düşük demokrasi kalite puanına (5.69) ${ }^{3}$ sahip olan ülkedir. Ayrıca, Şekil 1'de ülkelerin ortalama güven puanları refah rejimleri açısından karşılaştırılmıştır. Şekil 1 incelendiğinde, en yüksek ortalama güven puanına sahip olan refah rejiminin sosyal demokrat refah rejimi olduğu, onu sırasıyla liberal, muhafazakâr, Akdeniz ve sosyalist sonrası refah rejimlerinin takip ettiği görülecektir. Türkiye ise tam bir aykırı değer (outlier) statüsüne sahiptir ve Avrupa'nın diğer devletlerinden uzaklaşmış durumdadır.

Mevcut çalışmanın ikinci kısmında, sosyal demokrat rejimin en cömert ve en evrensel, muhafazakâr ve bir ölçüde de Akdeniz rejimlerinin cömert ancak seçici ve liberal ve sosyalist sonrası rejimlerin ise sınırlı ve seçici rejimler oldukları ifade edilmişti (Esping-Andersen, 1990). Bu durumda, dışlama hipotezi göz önünde bulundurulduğunda, en cömert ve evrensel rejimlerin yani devletin sosyal hayata en fazla müdahil olduğu refah rejimlerinin sivil toplumu en olumsuz şekilde etkileyen ve dolayısıyla sosyal sermayeyi ve güveni en fazla dışlayan rejimler olması gerekirdi. Ancak Tablo 1 ve Şekil 1'e göre durum neredeyse tam tersini göstermektedir. En cömert ve evrensel refah rejimi olan sosyal demokrat rejimi benimsemiş ülkelerde güven en yüksek seviyelerdeyken, cömert ancak sınırlı bir refah düzeni sağlayan muhafazakâr ve Akdeniz refah rejimlerini benimsemiş ülkelerde nispeten daha düşük güven seviyelerine rastlanmaktadir.

\footnotetext{
${ }^{2}$ Ülke serveti, kişi başına düşen yıllık gelir (Gross National Income per capita) ile dolar cinsinden ölçülmüştür.

${ }^{3}$ Demokrasi kalite puanlarına ulaşmak için: https://graphics.eiu.com/pdf/democracy\%20index\%202008.pdf
} 
Tablo 1. Refah Rejim Türleri ve Ülkeler Bazında Ülke Seviyesi Değişkenleri

\begin{tabular}{|c|c|c|c|c|}
\hline Refah Rejimi & Ülke & Ülke Serveti & Demokrasi Kalite Puanı & Güven \\
\hline \multirow{5}{*}{ Sosyal Demokrat } & Danimarka & 60390 & 9.52 & 6.99 \\
\hline & Norveç & 87350 & 9.68 & 6.66 \\
\hline & Finlandiya & 49920 & 9.25 & 6.48 \\
\hline & İsveç & 55380 & 9.88 & 6.41 \\
\hline & Hollanda & 52460 & 9.53 & 5.94 \\
\hline \multirow{2}{*}{ Liberal } & İ́landa & 50700 & 9.01 & 5.50 \\
\hline & Birleşik Krallık & 48420 & 8.15 & 5.36 \\
\hline \multirow{4}{*}{ Muhafazakâr } & İsviçre & 63020 & 9.15 & 5.80 \\
\hline & Belçika & 46710 & 8.16 & 5.16 \\
\hline & Almanya & 43870 & 8.82 & 4.91 \\
\hline & Fransa & 43510 & 8.07 & 4.47 \\
\hline \multirow{5}{*}{ Akdeniz } & İsrail & 25920 & 7.48 & 5.41 \\
\hline & İspanya & 32440 & 8.45 & 5.00 \\
\hline & Portekiz & 22440 & 8.05 & 3.97 \\
\hline & Yunanistan & 28660 & 8.13 & 3.93 \\
\hline & Türkiye & 9770 & 5.69 & 2.18 \\
\hline \multirow{9}{*}{ Sosyalist Sonras1 } & Çek Cumhuriyeti & 18300 & 8.19 & 4.73 \\
\hline & Hirvatistan & 13970 & 7.04 & 4.40 \\
\hline & Slovenya & 24710 & 7.96 & 4.34 \\
\hline & Ukrayna & 3220 & 6.94 & 4.19 \\
\hline & Polonya & 11990 & 7.30 & 4.18 \\
\hline & Litvanya & 12660 & 7.36 & 4.16 \\
\hline & Macaristan & 13220 & 7.44 & 4.16 \\
\hline & Rusya & 9590 & 4.48 & 4.09 \\
\hline & Romanya & 8630 & 7.06 & 3.85 \\
\hline Ortalama & & 33490 & 8.03 & 4.89 \\
\hline
\end{tabular}




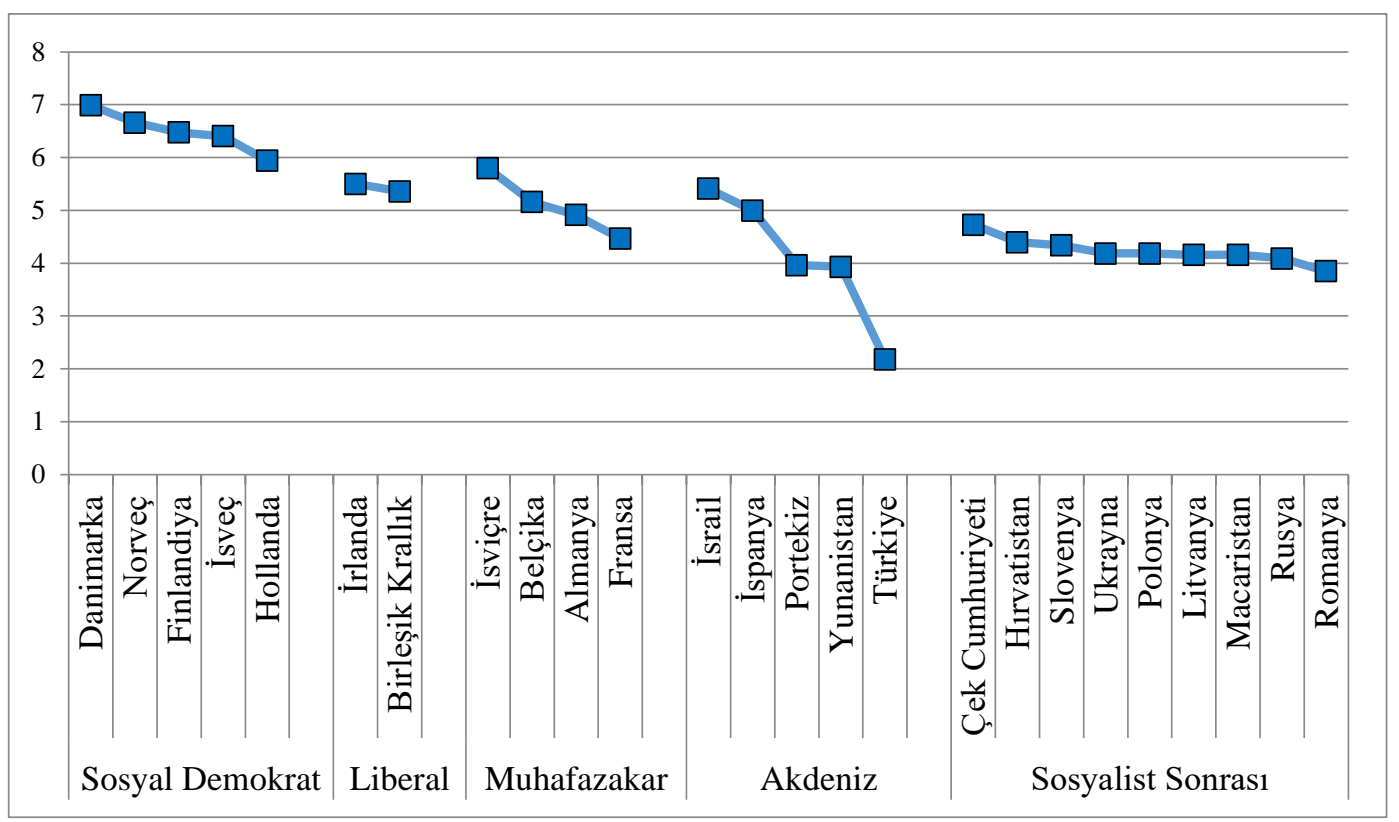

Şekil 1. Refah Rejim Türleri ve Ülkeler Bazında Ortalama Güven Değerleri

En düşük devlet müdahalesinin olduğu ve dolayısıyla sınırlı ve seçici bir refah yapısına sahip olan liberal ve sosyalist sonrası refah rejimlerini benimsemiş ülkeler ise güven sıralamasında tamamen ayrışmakta ve liberal rejimi benimsemiş olan İrlanda ve Birleşik Krallık, sosyal demokrat refah rejimini benimsemiş ülkelerden sonra en yüksek güven ortalamasına sahip ülkeler olurken, sosyalist sonrası refah rejimini benimsemiş ülkeler ise en düşük güven ortalamasına sahip ülkeler konumundadır. Bu durumda, Tablo 1 ve Şekil 1 esas alındığında, dışlama hipotezinin aksine pekiştirme hipotezinin kısmen de olsa doğrulandığını ifade etmek mümkündür. Yani, pekiştirme hipotezine göre, cömert ve evrensel refah rejimlerinde devlet, sosyal hayata daha fazla müdahil olmuş, böylece insanların bazı sorumluluklarını devlete devretmelerini ve bu sorumluluklara harcadıkları zaman, enerji ve maddi imkanlarını diğer insanlarla vakit geçirmeye ve iletişim ve etkileşim kurmaya harcamalarını sağlamış ve sonuç olarak onların sosyal sermayelerini ve diğer insanlara karşı besledikleri güveni pekiştirmiştir (dolaylı pekiştirme). Diğer bir ifadeyle, cömert ve evrensel refah rejimleri, eşitsizliklerin azaltılması yönünde eşit, adil, güvenilir ve tarafsız politikalar yürütmüş ve bu politikalarını güvenilir ve dürüst devlet görevlileri vasıtasıyla yapmış, bu sayede de vatandaşlarının en başta devlete, sonrasında ise devlet kurumlarına, devlet politikalarına, devlet görevlilerine ve son olarak da diğer insanlara güvenlerini pekiştirmişlerdir (dolaysız pekiştirme).

Buradaki tek istisna liberal rejimi benimsemiş olan İrlanda ve Birleşik Krallıktır. Çünkü her iki devlette de devlet müdahalesi çok sınırlı olduğundan dolayı, dolaylı bir pekiştirmeden ziyade dolaysız bir pekiştirmenin varlığı söz konusu olabilir. Yani, devlet müdahalesinin azlığı insanların sorumluluklarını devlete devretmelerini engeller. Bu da onların daha fazla sivil topluma katılıp sosyal sermayelerini ve güvenlerini pekiştirmelerine engel olur (dolaylı pekiştirme). Ancak, bu iki ülke uyguladıkları sınırlı ve seçici uygulamalarını adil, eşit ve tarafsız bir şekilde yürütüyorlarsa, bu durumda vatandaşlarının, en başta devlete ve devlet kurumlarına, sonrasında ise diğer insanlara karşı güvenlerini pekiştirmelerini (dolaysız pekiştirme) sağlayabilirler $\mathrm{Bu}$ aşamada, Tablo 1 ve Şekil 1'deki bulguları daha detaylı yorumlamak ve Türkiye'ye yönelik değerlendirmelerde bulunmak amaciyla, Yuksek ve Solakoglu'nun (2019) çalışmasında incelenen üç birey seviyesi değişkeni (refah devletinin gücüne, refah politikalarının sonucuna ve refah politikaları ile politikaları yürüten devlet görevlilerinin meşruiyetine yönelik birey 
tutumları) ile iki ülke değişkeninin (ülke serveti ve ülke demokrasi kalitesi) güveni ne şekilde etkilediği üzerinde durulacaktır. ${ }^{4}$

Yuksek ve Solakoglu'nun (2019) çalışmasında incelenen ilk birey seviyesi değişkeni, bireyin refah devletinin gücüne (evrenselliği, kapsayıcılığı) yönelik tutumudur. Birey tutumlarının geçmiş deneyimlere bağlı olarak geliştiği göz önünde bulundurulduğunda (Katz, 1960), daha güçlü bir refah devletinin varlığını isteyen, yani toplumun işleyişine daha fazla devlet müdahalesinin olması gerektiğini savunan bir bireyin, bu tutumunun deneyimlediği yetersiz devlet müdahalesinden ve vatandaşı olduğu zayıf bir refah devletinin varlığından kaynakladığını ifade etmek mümkündür. Yetersiz refah politikalarıyla donatılmış güçsüz bir refah devleti, bireylerin birbirlerine karşı olan sorumluluklarını devralamaz ve bu da insanların mevcut zaman, enerji ve maddi imkanlarını sosyalleşme çabalarına yöneltmelerini engeller. Sonuçta, pekiştirme hipotezinde ifade edildiği gibi, güçsüz refah devleti güçsüz bir sivil toplumun oluşmasını pekiştirir ve bu da bireylerin sosyalleşme gayretlerini azalttığı gibi birbirlerine karşı güven duygusu geliştirmelerini de engeller (dolaylı pekiştirme). Yani, bireyler refah devletinin yoğun bir şekilde sosyal hayata müdahil olmasını ne kadar çok isterlerse, bu durum aslında o oranda zayıf bir refah devletinin varlığına işaret eder; refah devleti ne kadar zayıfsa, bu da o oranda zayıf bir sivil toplumun varlığını ve bireylerin diğer bireylere o oranda daha az güven duyduklarını gösterir.

Ancak bu olumsuz durum Şekil $2^{5}$ ve Şekil 3’te görüldüğü gibi, ülke serveti ve ülke demokrasi kalitesi göz önünde bulundurulduğunda ortadan kalkmaktadır. Esping-Andersen'e (1990) göre, etkin demokrasi ve nispeten yüksek bir yaşam standardı refah devletinin temelini oluşturmaktadır. Bu ifade üzerine şu şekilde bir çıkarımda bulunulabilir: bir ülkenin demokrasi kalitesi ve serveti ne kadar büyükse, o ülkenin güçlü ve evrensel bir refah devleti olma ihtimali ve dolayısıyla refah harcamalarının yüksek seviyelerde olması ihtimali de o kadar büyük olacaktır. Bu kapsamda, Şekil 2 ve Şekil 3'e göre, ülkelerin zenginleşmesi ve demokratikleşmesi o ülke vatandaşlarının diğer insanlara daha fazla güven duymalarına sebep olmaktadır (örn. Finlandiya ve Norveç gibi). Bu durum ise şu şekilde açıklanabilir: zengin ve demokratik ülkeler (yani güçlü refah devletleri), uyguladıkları refah devleti politikalarıyla sivil topluma ve sosyal sermayeye olumsuz bir etki yapabiliyor olsalar da (dışlama hipotezinde iddia edildiği gibi), politikalarının eşitliği, tarafsızlığı ve adaleti esas alması ve bu politikaları uygulayan devlet görevlilerinin muhatap olduğu bireylere adil, eşit ve dürüstçe davranması sosyal sermaye üzerine oluşabilecek olumsuz etkinin ortadan kalkmasına sebep olmaktadır. Bunun en bariz örneği İskandinav ülkeleridir (Kumlin ve Rothstein, 2005). Ancak, nispeten fakir olan ve zayıf bir demokrasiye sahip olan ülkeler incelendiğinde ise (yani zayıf refah devletleri), ülkeler sınırlı ve seçici refah politikaları uyguluyor olsalar dahi sosyal sermayeyi ve güveni olumsuz etkilemektedirler. Bu durum, Knack ve Keefer'in (1997) zengin ülkelerde yaşayan bireylerin fakir ülkelerde yaşayan bireylere nazaran diğer bireylere karşı daha fazla güven duyma eğiliminde oldukları bulgusu ile Uslaner'in (2003) demokrasisi güçlü ülkelerde yaşayan bireylerin

\footnotetext{
4 Türkiye özelinde değerlendirmelerde bulunmak maksadıyla: (1) Yuksek ve Solakoglu'ndan (2019) çalışmalarında kullandıkları veri seti talep edilmiş; (2) bu veri seti ile, Yuksek ve Solakoglu'nun (2019) çalışmalarına dahil ettikleri tüm değişkenler (uygulanan işlevselleştirmeler birebir aynı olacak şekilde) kullanılarak Türkiye'ye yönelik katsayı (coefficient) değerlerinin elde edileceği analizler yapılmış; (3) her değişken için elde edilen katsayı değeri, ilgili değişkenin ortalama değeri ile çarpılmış; (4) sadece üç birey seviyesi değişkeni ile iki ülke seviyesi değişkeninin katsayı değerleri, refah devletine yönelik birey tutumlarının, ülke servetinin ve ülke demokrasi seviyesinin birey seviyesindeki değişkenliğinin yansıtılması amacıyla söz konusu değişkenlerin farklı değerleri ile çarpılmış; (5) çarpımlar sonucu elde edilen tüm değerler toplanarak farklı ülkelerden bireylerin farklı birey seviyesi değişken değerlerine göre tahmini güven değerleri hesap edilmiştir. Hesap edilen bu değerler tablolara işlenerek Şekil 2-Şekil 7 hazırlanmıştır.

5 Çalışmadaki tüm şekillerde (Şekil 1 hariç) Türkiye dişında beş ülke gösterilmektedir. Bu ülkelerin seçimi için model çalışmaya dahil edilen 25 ülkenin tamamı hem ülke serveti hem de ülke demokrasi kalitesi açısından en düşük değere sahip ülkeden (1. sıradaki) en yüksek değere sahip olan ülkeye (25. sıradaki) doğru sıralanmış ve bu sıralama doğrultusunda 1., 7. , 13., 19. ve 25. ülkeler şekillerde gösterim maksadıyla seçilmiştir. Ülke servetini konu alan şekillerde gösterilmek maksadıyla Türkiye dışında seçiler ülkeler şunlardır: Ukrayna (1.), Macaristan (7.), Yunanistan (13.), Finlandiya (19.) ve Norveç (25.). Ülke demokrasi kalitesini konu alan şekillerde gösterilmek maksadıyla Türkiye dışında seçilen ülkeler şunlardır: Rusya (1.), Litvanya (7.), Yunanistan (13.), İrlanda (19.) ve İsveç (25.).
} 
demokrasisi etkin olarak işlemeyen ya da antidemokratik ülkelerde yaşayan bireylere nazaran diğer bireylere karşı daha fazla güven duyma eğiliminde oldukları bulgusunu desteklemektedir.

Bu kapsamda, Türkiye'nin durumunu şu şekilde ifade etmek mümkündür: Türkiye, Akdeniz refah rejimi özellikleri ile sınırlı ve seçici refah politikaları yürütmektedir. Türkiye'nin mevcut servet ve demokrasi kalitesi seviyesi sabit tutulduğunda, politikalarını tüm vatandaşlarını kapsayacak şekilde genişletmesi ve

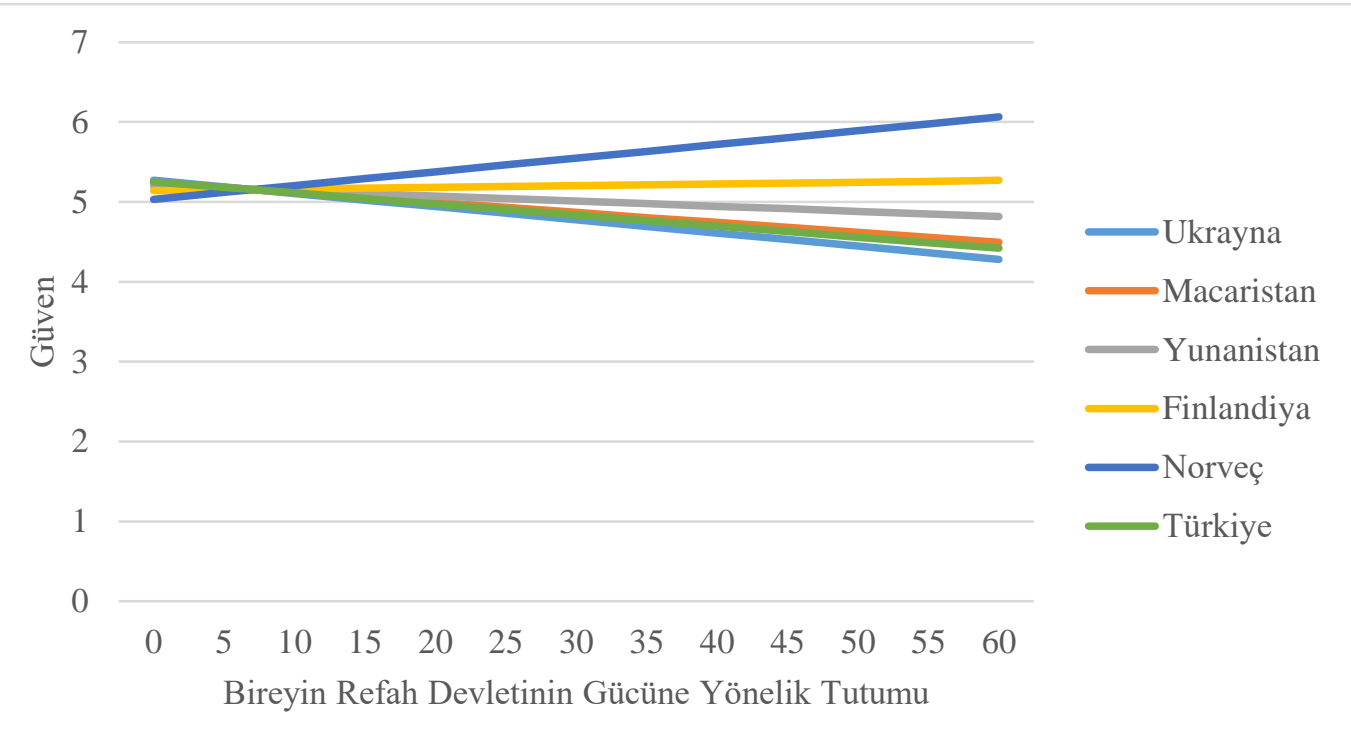

Şekil 2. Bir Ülkenin Servetinin, Bireyin Refah Devletinin Gücüne Yönelik Tutumu ile Diğer Bireylere Karş1 Beslediği Güven Arasındaki İlişki Üzerine Olan Etkisi

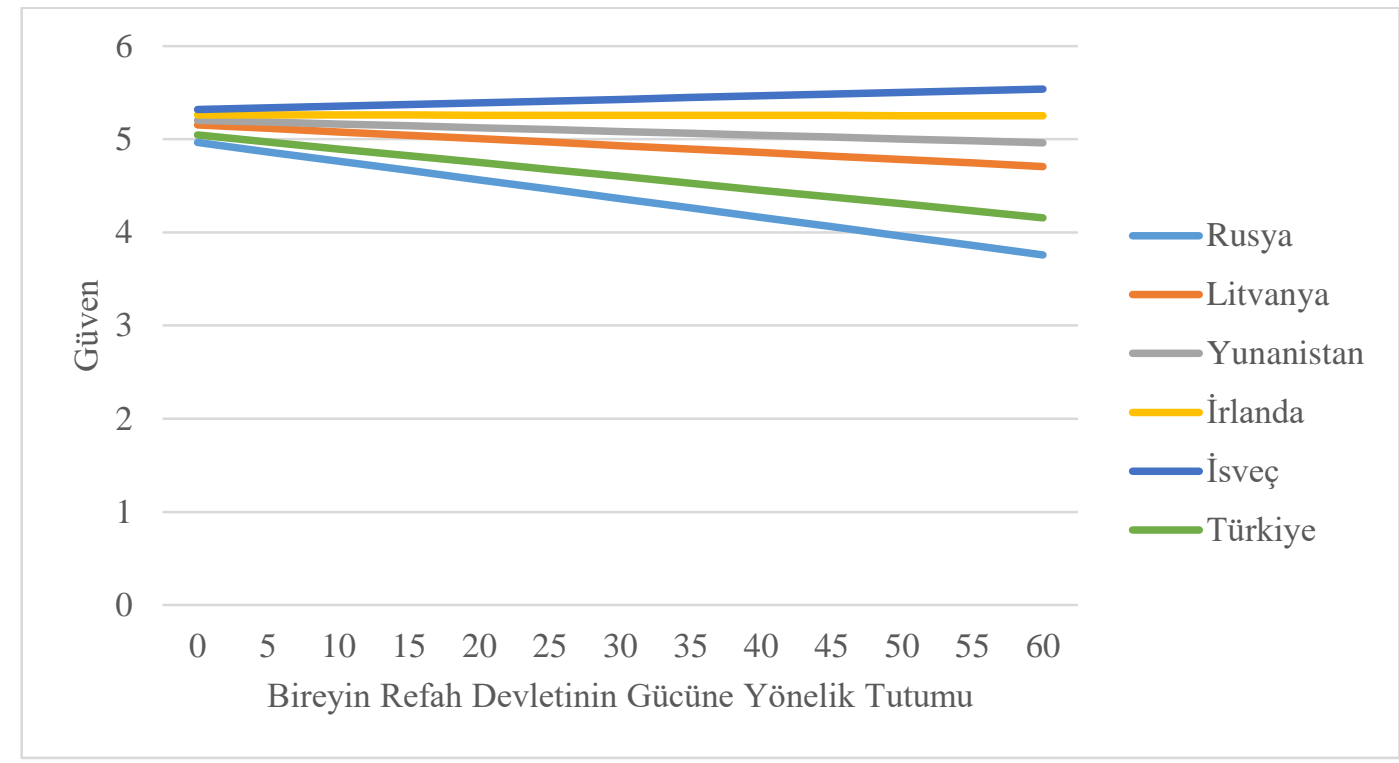

Şekil 3. Bir Ülkenin Demokrasi Kalitesinin, Bireyin Refah Devletinin Gücüne Yönelik Tutumu ile Diğer Bireylere Karşı Beslediği Güven Arasındaki İlişki Üzerine Olan Etkisi

evrenselleştirmesi, yani sosyal hayata daha fazla müdahil olması, sosyal sermayeyi olumsuz yönde etkileyecek ve bireylerin birbirlerine karşı duydukları güveni azaltacaktır (Şekil 2 ve Şekil 3). Şekil 2 ve Şekil 3'te görüldüğü üzere, Türkiye'de refah devletinin güçlü bir şekilde sosyal hayata müdahil olmasının, sosyal sermayeyi olumsuz etkilemesinin ve güveni dışlamasının arka planındaki esas sebep ise şu şekilde ifade edilebilir: Sosyalist sonrası ve nispeten Akdeniz refah rejimini benimsemiş ülkelerin (Türkiye de bu gruba dahildir), bireylerin birbirlerine karşı besledikleri güveni azaltmasının sebebi, bu ülkelerin zenginliği/fakirliği veya demokratik/antidemokratik olmalarından ziyade, bu iki ülke değişkenine bağlı olarak yürütmekte oldukları politikalarının güvenilir, adil, eşit ve tarafsız bir şekilde yürütülüp 
yürütülmediğidir. Bir devlet, zaten sınırlı ve seçici olan refah yardımlarını toplumun genelini kapsayacak şekilde artırsa dahi, faydalandıracağı kişileri seçerken adil ve tarafsız davranmazsa, bireylerin sistemi kandırmasına ve rüşvetin yaygınlaşmasına izin verirse ve yozlaşmış devlet görevlilerinin faaliyetlerine göz yumarsa, bireyler, vatandaşı oldukları devlet refah yardımlarını artırsa dahi sistemin çarpıklığı sebebiyle gerçekten hak edenlerin bu yardımlardan faydalanamayacaklarını bilmeleri sebebiyle devlete, kurumlarına, görevlilerine ve devletin yozlaşmışlığını kabul edip tepki göstermeyen ve gerekirse devleti kandırmaya çalışabileceklerine inandıkları diğer insanlara da güvenmez, güveniyorlarsa da bu güven azalma eğilimi gösterir.

Yuksek ve Solakoglu'nun (2019) çalışmasında incelenen ikinci birey seviyesi değişkeni, bireyin refah politikalarının sonucuna (olumlu ya da olumsuz) yönelik tutumudur. Esping-Andersen'e (1990) göre, refah devletleri, politikalarını başarılı bir şekilde uygulayarak, yoksulluk, işsizlik ve tam ücret bağımlılığını ortadan kaldırabilir. Böylece, bireylerin politik kapasitelerini artırabilir, eşitlikçi bir kaynak dağılımını teşvik edebilir, bireyler arasında birlik ve bütünlüğü engelleyen sosyal bölünmeleri azaltabilir ve nihayet bireylerin birbirlerine daha fazla güven duymalarını sağlayabilir. Bu durumda, birey, ülkesinin sağladığı refah devleti politikalarıyla olumlu deneyimler yaşamış ve olumlu sonuçlar elde etmişse, yani refah devleti politikaları başarılı olmuş ve toplumun tüm kesimlerini kapsayan bir etki göstermişse, bireyin ülkesine ve politikalarına yönelik olarak olumlu bir tutum geliştirmesi beklenir. $\mathrm{Bu}$ tutum da, birbirlerinden farklı olduklarına inandıkları bireyleri birbirlerine yakınlaştırır ve diğer bireylere karşı güven duymalarını sağlar.

Yuksek ve Solakoglu (2019), deneyimlenen olumlu sonuçlar ile güven arasında anlamlı pozitif bir ilişki tespit etmiştir. Ancak, ülkenin serveti ve demokrasi kalitesi hesaba katıldığında bu pozitif ilişki ülkelere göre farklılaşmaktadır. Şekil 4 ve Şekil 5'te görüldüğü üzere, fakir ve demokrasisi gelişmemiş ülkelerde deneyimlenen olumlu sonuçların güven üzerinde bir etkisi yoktur (örn. Ukrayna, Macaristan ve Türkiye gibi). Özellikle, Türkiye hem ülke serveti hem de demokrasi açısından, Rusya demokrasi açısından ve Ukrayna ve Macaristan da ülke serveti açısından bu konumdaki ülkelerdir (Tablo 1'e bakınız). Ancak, ülkeler zenginleştikçe ve demokratikleştikçe olumlu deneyimlerin güven üzerine olan pozitif etkisi açık olarak görülebilir. Rusya, Türkiye ve Macaristan'ın durumu detaylı incelendiğinde, bu ülkelerin sahip oldukları refah rejimleri dolayısıyla sınırlı ve seçici uygulamaları, bu uygulamalardan faydalanan sınırlı sayıdaki bireyde dahi gerçek manada yaşam kalitesi ve eşitsizliği azaltma bakımından etkili olamamaktadır. Bu uygulamalardan faydalanamayan nüfusun geri kalan çoğunluk kısmında ise, uygulamaların seçici olması sebebiyle devlete karşı bir güvensizlik oluşmaktadır. Seçilenlerin yerine kendilerinin seçilmesi gerektiği fikri de bu güvensizliği pekiştirmektedir. Sonuç olarak, tüm bu olumsuzluklar, bu ülkelerin refah devleti politikalarının, bireylerin devlete, devlet kurumlarına ve diğer bireylere olan güveni pekiştirememelerine sebep olmaktadır. Aksine, zengin ve nispeten daha güçlü demokrasilere sahip olan Norveç, Finlandiya ve İsveç gibi ülkelerdeki adaletli ve kapsamlı uygulamalar, bu ülkelerin sahip oldukları evrensel refah sağlama gayretleri sebebiyle neredeyse ülke nüfusunun tamamını kapsamakta, bu sebeple de refah programlarından faydalanan tüm bireylerde öncelikle devlete ve devlet kurumlarına, sonrasında ise diğer bireylere karşı güveni pekiştirmektedir. 


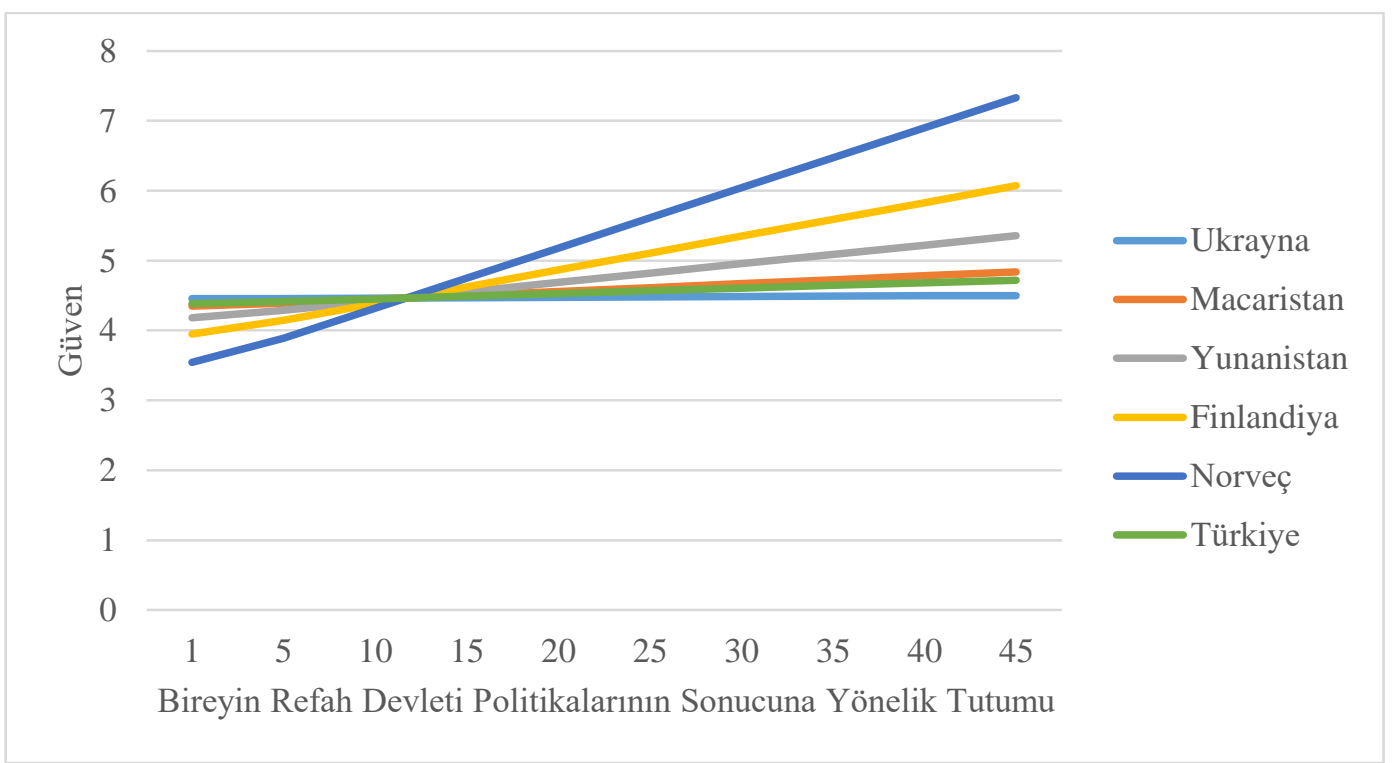

Şekil 4. Bir Ülkenin Servetinin, Bireyin Refah Devleti Politikalarının Sonucuna Yönelik Tutumu ile Diğer Bireylere Karşı Beslediği Güven Arasındaki İlişki Üzerine Olan Etkisi

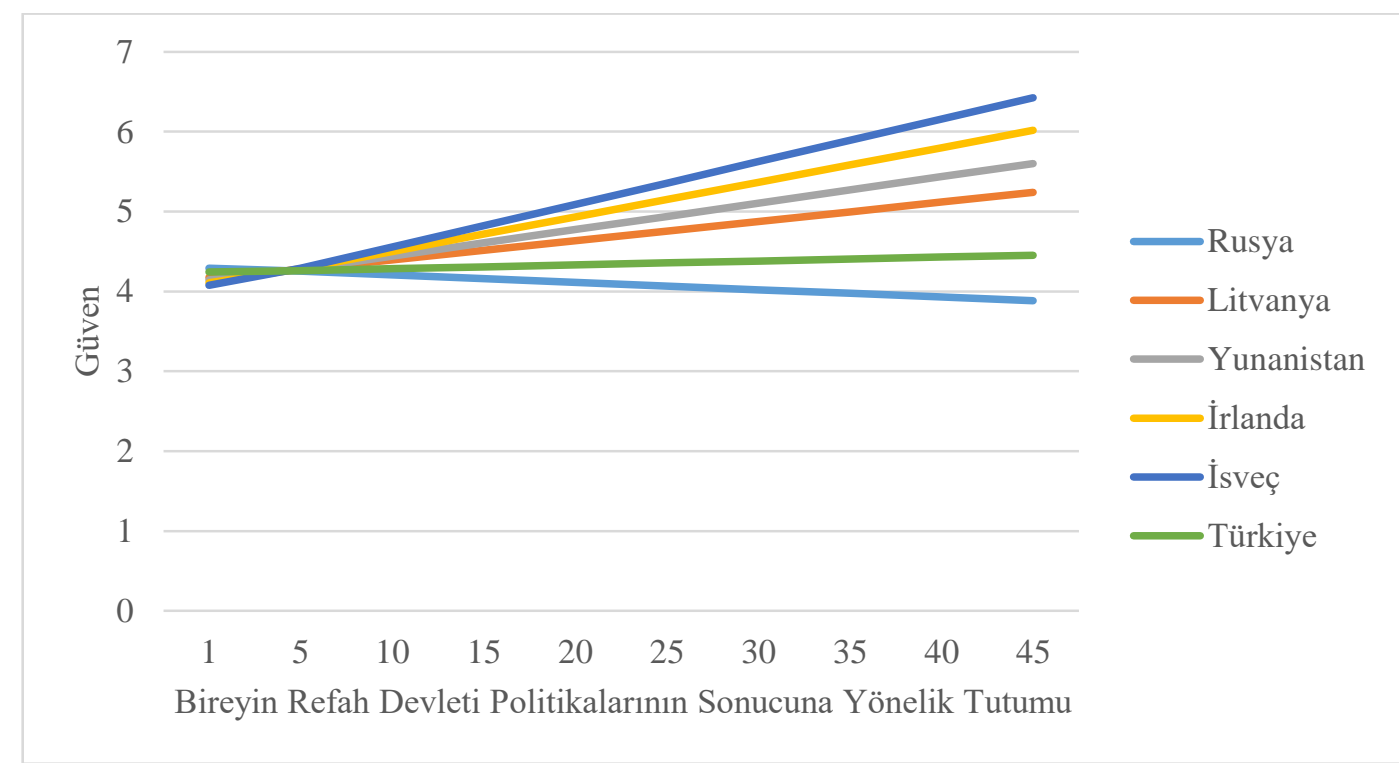

Şekil 5. Bir Ülkenin Demokrasi Kalitesinin, Bireyin Refah Devleti Politikalarının Sonucuna Yönelik Tutumu ile Diğer Bireylere Karşı Beslediği Güven Arasındaki İlişki Üzerine Olan Etkisi

Ayrıca, zengin ülkelerde ortaya çıkan ilginç bir durum Şekil 4'te görülmektedir. Bu tür ülkelerin (örn., Norveç ve Finlandiya) vatandaşları, sağlanan refah uygulamalarından olumlu deneyimler elde ettiklerinde daha fakir ülkelerin vatandaşlarına kıyasla diğer bireylere karşı daha fazla güven beslemektedirler. Ancak, dikkat edilirse görülecektir ki, bu ülkelerin vatandaşları sağlanan refah uygulamalarından olumlu deneyimler elde edemezlerse daha fakir ülkelerin vatandaşlarına kıyasla diğer bireylere karşı daha az güven beslemektedirler. Bunun sebebi ise, güçlü ve evrensel bir refah rejimine sahip olan ülke vatandaşlarının, ülkelerinin kendilerine olumlu deneyimler yaşatacak etkin ve faydalı politikalar geliştirmeleri yönündeki beklentileridir. Bu tür bir durum Türkiye, Ukrayna ve Macaristan gibi ülkelerde görülmemektedir. Bunun bir sebebi de bu ülkelerde yaşayanların Norveç, Finlandiya veya İsveç gibi ülkelerde yaşayan bireylerin beklentilerine benzer beklentiler geliştirmemeleri olabilir. Neden geliştirmedikleri sorusunun cevabı ise ülkenin demokrasi tarihi ve vatandaşların demokrasi anlayışları ile ülke politikalarında, politikaları yürüten bürokratlarda ve vatandaşlar ile direkt temas halinde olan devlet görevlilerinin tavır ve davranışlarında aranmalıdır. 
Yuksek ve Solakoglu'nun (2019) çalışmasında incelenen son birey seviyesi değişkeni ise, bireyin refah devleti politikaları ile bu politikaları uygulayan devlet görevlilerinin meşruiyetine yönelik tutumudur. İnsanlar, genel olarak, refah politikalarının ülke vatandaşlarının tamamına adil ve eşit bir şekilde uygulanmasını bekler ve isterler. Uygulanan refah rejimine bağlı olarak (örn., sosyal demokrat veya Akdeniz) refah politikalarının ülke vatandaşlarının tamamına faydalandırılması uygulaması farklılıklar gösterse bile, uygulanan refah rejiminden bağımsız olarak, insanların refah devletinden beklentisi refah politikalarının bireylere eşit ve adil bir şekilde uygulanmasıdır. İnsanlar, refah politikalarının uygulanmasından sorumlu olan kurum ve görevlilerin adil, etkin ve herkese eşit bir şekilde davrandıklarına ve diğer bireylerin de bu kurum ve görevliler hakkında benzer şekilde düşündüklerine inanırlarsa, diğer bireylere güven duyarlar (Rothstein, 2000). Bu da refah devleti politikalarını uygulayan kurum ve görevlilerin adalet derecesi ve tarafsızlığının bu kurum ve görevlilere yönelik güveni pekiştirdiğini ve bu güvenin de diğer bireylere yönelik güvene yansıdığını gösterir. Bunun sebebi, insanların politikacılar ve devlet görevlileriyle yaşadıkları deneyimleri diğer bireylere yansıtma eğiliminde olmasıdır (Rothstein ve Stolle, 2003). Bu tartışma ışığında, bir birey yaşadığı ülkenin refah politikalarından adil ve eşit bir şekilde faydalanmış ve devlet görevlileriyle tarafsız ve güvenilir etkileşimlerde bulunmuşsa, bu birey, devlete, devlet kurumlarına, devlet görevlilerine ve son olarak da diğer bireylere daha fazla güven duyar. Aksine, adil ve tarafsız deneyimler yaşanmamışsa, refah devleti, politikaları ve görevlileri vasıtasıyla güvensizliği pekiştirmiş olur. Yuksek ve Solakoglu (2019), refah devleti politikalarının adaletsiz uygulanması ve devlet görevlilerinin tarafsız ve haksız eylemlerinin bireylerde güvensizliği pekiştirdiğini tespit etmiştir. Bu duruma ülkenin serveti ve demokrasi kalitesi dahil edildiğinde ise daha ilginç sonuçlar ortaya çıkmaktadır.

Şekil 6 ve Şekil 7'de görüldüğü üzere, ülkenin zengin veya fakir, demokratik veya antidemokratik olup olmadığına bakılmaksızın, taraflı devlet politikaları ve adil olmayan devlet görevlisi etkileşimleri, bireyleri diğer bireylere daha az güvenmeye itmektedir. Ancak, daha güçlü refah devletlerine sahip olan zengin ve demokratik İsveç, Norveç ve Finlandiya gibi ülkelerde, bireylerin diğer bireylere olan güvensizliği devlet politikalarına ve görevlilerine karşı olan güvensizlik arttıkça daha güçlü bir şekilde artmaktadır. Bunun sebebi ise, insan hakları, adalet ve eşitlik gibi değerlerin insan hayatında çok önemli bir yer tuttuğu ve vazgeçilmez olarak kabul edildiği bu ülkelerde yaşayanların, ülkelerinden olumsuz sonuçlar doğuracak politikalar beklememeleri ve devlet görevlilerinden de adil ve dürüst bir muamele beklemeleridir. Ancak, bu beklentiler karşılanmamışsa, devlete, devlet kurumlarına, görevlilerine ve son olarak da diğer bireylere duyulan güven diğer ülkelerle kıyaslandığında daha sert bir şekilde düşmektedir. 


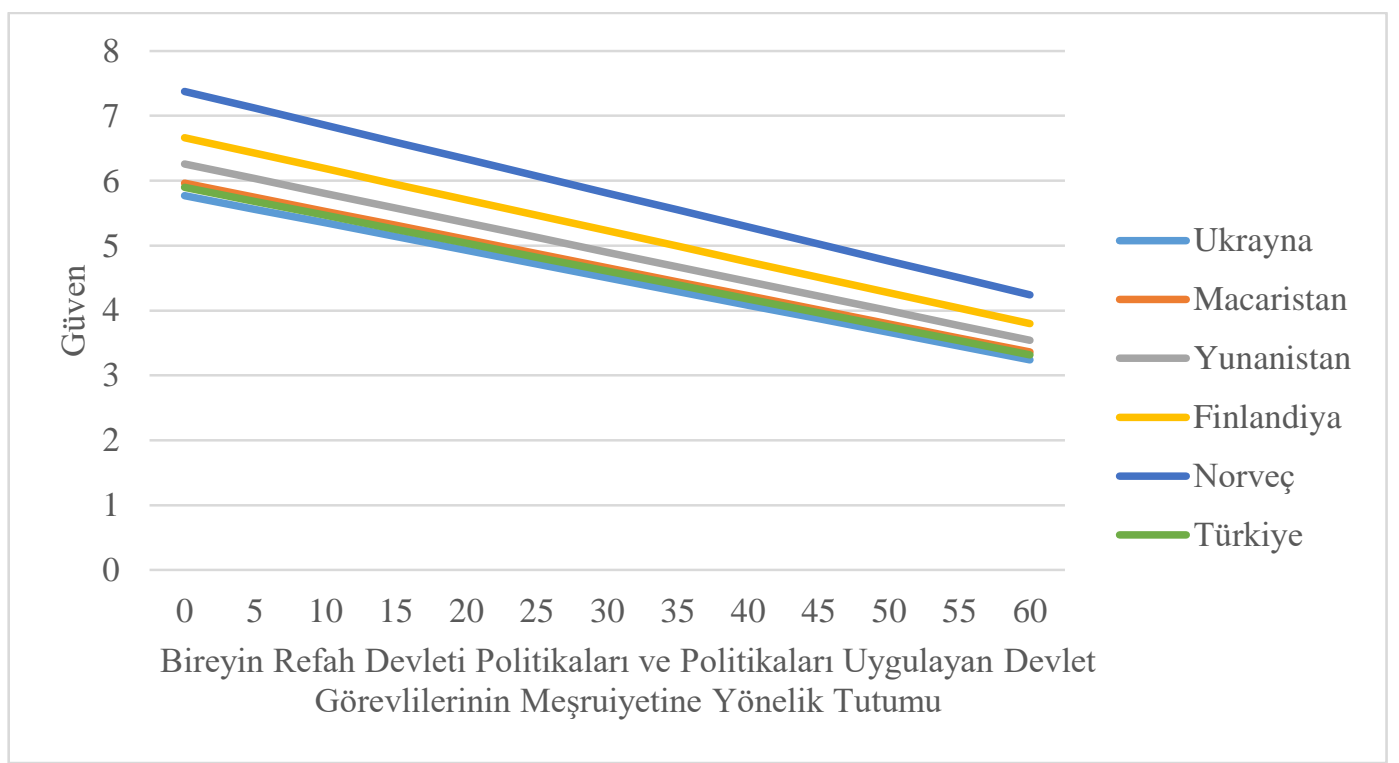

Şekil 6. Bir Ülkenin Servetinin, Bireyin Refah Devleti Politikaları ve Politikaları Uygulayan Devlet Görevlilerinin Meşruiyetine Yönelik Tutumu ile Diğer Bireylere Karşı Beslediği Güven Arasındaki İlişki Üzerine Olan Etkisi

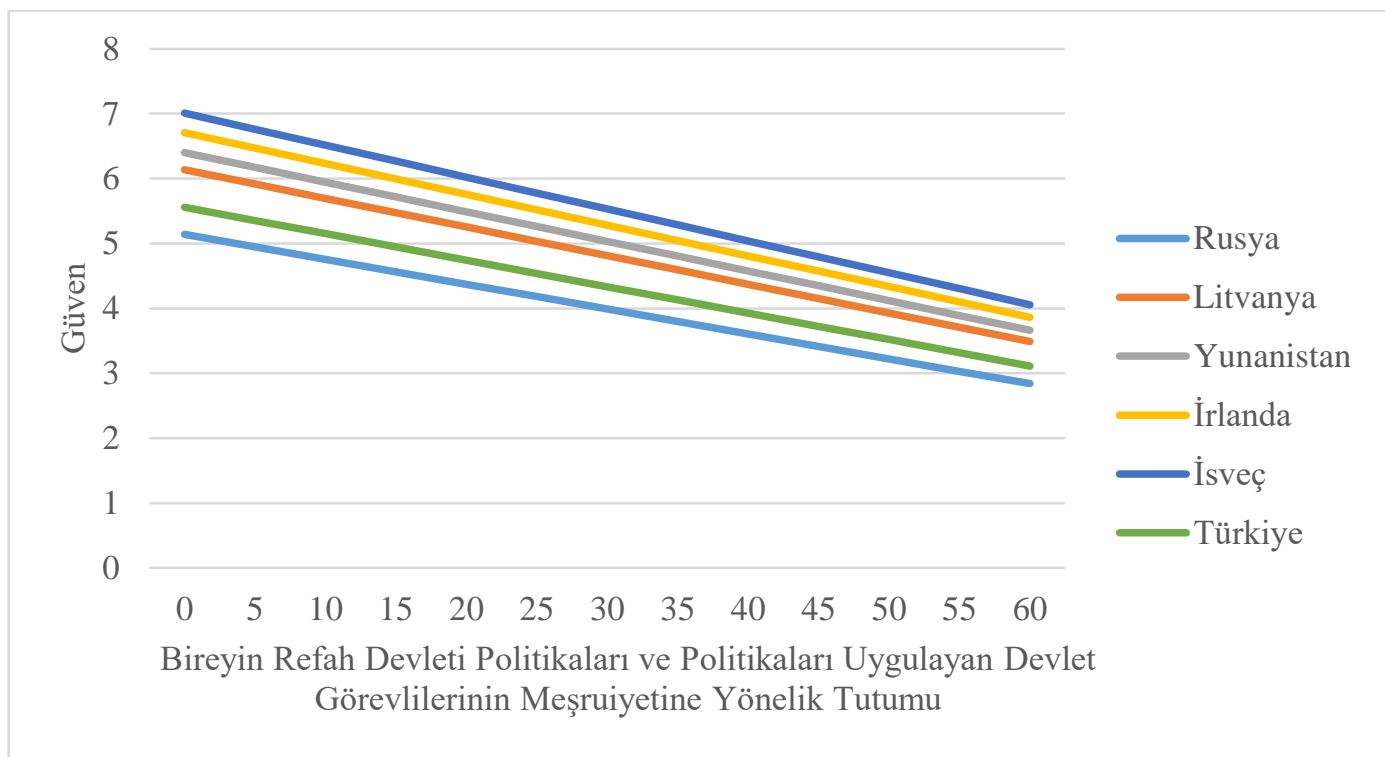

Şekil 7. Bir Ülkenin Demokrasi Kalitesinin, Bireyin Refah Devleti Politikaları ve Politikaları Uygulayan Devlet Görevlilerinin Meşruiyetine Yönelik Tutumu ile Diğer Bireylere Karşı Beslediği Güven Arasındaki İlişki Üzerine Olan Etkisi

Türkiye'de ise, Şekil 6 ve Şekil 7 incelendiğinde, taraflı devlet politikaları ve devlet görevlileriyle etkileşime bağlı olarak bireyler arası güvende bir düşüş görülmektedir. Ancak, olumsuzluk arttıkça görülmesi beklenen güvendeki daha sert düşüşler Batı Avrupa ülkeleriyle kıyaslandığında görülmemektedir. Bu da Türkiye'de yaşayan bireylerin beklentilerinin yönünü ve bu bireyler için Batı Avrupa ülkelerinde yaşayanlara kıyasla taraflı, haksız ve eşit olmayan deneyimlerin normalleşmiş olabileceğinin bir göstergesidir. Bunun bir sebebi ise, Türkiye'de insan hakları, adalet ve eşitlik gibi değerlerin vazgeçilmez bir haktan ziyade bir lüks gibi algılanıyor olması olabilir. Bu sebeple de adaletsiz ve taraflı refah devleti politikaları ve bu politikaların vatandaşlara yansımasını sağlayan devlet görevlilerinin yozlaşmış tavır ve davranışları güveni olumsuz yönde etkilese de, bu olumsuzlukların artmasının diğer ülkelere kıyasla güvende çok daha sert bir düşüşe sebep olmadığı ifade edilebilir. 


\section{Sonuç}

$\mathrm{Bu}$ çalışmada, refah devleti ve sosyal sermaye arasındaki ilişki ile dışlama ve pekiştirme hipotezleri teorik olarak incelenmiş, bu konuda literatürde Türkiye'yi ele alan bir çalışmanın bulunmaması sebebiyle Yuksek ve Solakoglu'nun (2019) çalışması model olarak alınmış ve model çalışma esas alınarak Türkiye'de yaşayan bireylerin refah devletine, refah politikalarına ve politika uygulayıcılara yönelik tutumlarının sosyal sermayeye etkisi üzerine değerlendirmelerde bulunulmuştur. Böylece mevcut literatüre önemli bir katkı yapılması amaçlanmıştır.

Çalışma sonucunda güçlü ve evrensel refah devletlerinin sosyal sermayeyi ve güveni dışlamadığı aksine pekiştirdiği tespit edilmiştir. Ayrıca, Rusya ve Türkiye'nin dışındaki ülkelerin, güçlü ve evrensel refah programları uygulamasalar dahi, yani sosyal demokrat refah rejimini benimsemiş olmasalar dahi, bireylerin olumlu deneyimler yaşayacakları ve olumlu tutumlar geliştirebilecekleri politikalar vasıtasıyla güveni pekiştirebilecekleri tespit edilmiştir (Şekil 4 ve Şekil 5). Türkiye ve Rusya bu konuda istisnadırlar. $\mathrm{Bu}$ iki ülke, olumlu birey tutumları oluşturabilecek refah devleti politikaları geliştirseler dahi, bireyler arası güveni pekiştirememektedirler.

Dışlama hipotezi özellikle bazı sosyalist sonrası refah rejimini benimsemiş ülkeler ile Türkiye'de doğruluğu kanıtlanabilir durumdayken (Şekil 2 ve Şekil 3), bunu diğer ülkeler açısından kabul etmek oldukça güçtür. Ülkeler sivil topluma ve vatandaşlarının sosyal hayatına daha fazla müdahil olsalar da, bu durumun sosyal sermayeyi çok sınırlı bir şekilde azalttığını ifade etmek mümkündür. Çünkü, Avrupa'nın birçok ülkesi güçlü refah rejimleriyle yönetilmektedir ve bu ülkeler yine de yüksek sosyal sermayeye sahiptir. Bu sebeple, yürüttükleri eşit ve adil politikalarla adaletli bir kaynak dağılımı sağlayan ve eşitlikçi bir toplum yaratmayı amaçlayan refah devletleri, sivil topluma ve sosyal hayata fazlaca müdahil olsalar dahi sosyal sermayeyi ve güveni dişlamazlar. Aksine, yürüttükleri adaletsiz ve taraflı politikalarla ve yozlaşmış devlet görevlileri ve yozlaşmış bir sistemle eşitliği sağlama gayreti içinde olmayan refah devletleri, sivil topluma ve sosyal hayata hiç müdahil olmasalar dahi sosyal sermayeyi ve güveni dışlamaktadırlar. Bu kapsamda, bu çalışma ile şu sonuca varılabilir: evrensel ve kapsayıcı politikalar yürüten güçlü refah devletleri sosyal sermayeyi pekiştirmede veya çok da mümkün görünmese de dışlamada bir etkiye sahip olsalar dahi, sosyal sermayeyi esas anlamda artıracak ya da azaltacak olan, bu refah devletlerinin uyguladıkları politikaların amacı, politikaların uygulanma şekli ve bu politikaları uygulayanların tavır ve davranışlarıdır.

\section{Kaynakça}

Alp, S. (2009). Refah devleti düşüncesinin gelişimi ve bir liberal alternatif olarak üçüncü sektör. Maliye Dergisi, 156, 265-279.

Arts, W., Gelissen, J. (2002). Three worlds of welfare capitalism or more? A state of-the-art report. Journal of European Social Policy, 12(2), 137-158.

Briggs, A. (1961). The welfare state in historical perspective. European Journal of Sociology, 2(2), 221258.

Delhey, J., Newton, K. (2003). Who trusts?: The origins of social trust in seven societies. European Societies, 5(2), 93-137.

Eagly, A., Chaiken, S. (2005). Attitude research in the $21^{\text {st }}$ century: The current state of knowledge. In D. Albarracin, B. T. Johnson ve M. P. Zanna (Der.), Handbook of attitudes (ss. 743-767). Mahwah, NJ: Erlbaum.

Elveren, M. A., Elveren, A. Y. (2010). Türkiye'de refah rejiminin dönüşümü ve bireysel emeklilik sistemi. Mülkiye Dergisi, 266, 243-258.

Esping-Andersen, G. (1990). The three worlds of welfare capitalism. Polity Press.

Etzioni, A. (1995). The spirit of community. London: Fontana Books. 
Fukuyama, F. (1995). Trust: The social virtues and the creation of prosperity. New York: The Free Press. Fukuyama, F. (2001). Social capital, civil society, and development. Third World Quarterly, 22(1), 7-20.

Kaariainen, J., Lehtonen, H. (2006). The variety of social capital in welfare state regimes-A comparative study of 21 countries. European Societies, 8(1), 27-57.

Katz, D. (1960). The functional approach to the study of attitudes. Public Opinion Quarterly, 24(2), 163204.

Knack, S., Keefer, P. (1997). Does social capital have an economic payoff? Quarterly Journal of Economics, 112, 1251-1288.

Kumlin, S., Rothstein, B. (2005). Making and breaking social capital: The impact of welfare-state institutions. Comparative Political Studies, 38(4), 339-365.

Newton, K. (2001). Trust, social capital, civil society, and democracy. International Political Science Review, 22(2), 201-214.

Özdemir, S. (2005). Sosyal gelişim düzeyleri farklı refah devletlerinin sınıflandırılması üzerine bir inceleme. Sosyal Siyaset Konferansları Dergisi, 49, 231-266.

Portes, A. (1998). Social capital: Its origin and applications in modern sociology, Annual Review of Sociology, 24, 1-24.

Putnam, R. D. (2000). Bowling alone: The collapse and revival of American community. Simon and Schuster.

Rostila, M. (2013). Social capital and health inequality in European welfare states. Palgrave Macmillan.

Rothstein, B. (1998). Just institutions matter: The moral and political logic of the universal welfare state. Cambridge: Cambridge University Press.

Rothstein, B., Stolle, D. (2003). Social capital, impartiality and the welfare state: An institutional approach. In M. Hooghe ve S. Dietlind (Der.), Generating social capital: Civil society and institutions in comparative perspective (ss. 191-211). New York, NY: Palgrave Macmillan.

Sabatini, F. (2009). Social capital as social networks: A new framework for measurement and an empirical analysis of its determinants and consequences. The Journal of Socio-Economics, 38, 429-442.

Scheepers, P., Te Grotenhuis, M., Gelissen, J. (2002). Welfare states and dimensions of social capitalCross national comparisons of social contacts in European countries. European Societies, 4, 185207.

Stadelmann-Steffen, I. (2011). Social volunteering in welfare states: Where crowding out should occur. Political Studies, 59, 135-155.

Stolle, D. (2003). The sources of social capital. In M. Hooghe ve S. Dietlind (Der.), Generating social capital: Civil society and institutions in comparative perspective (ss. 19-43). New York, NY: Palgrave Macmillan.

Taşçı, F. (2013). Refah devleti modelleri içinde Türkiye'nin pozisyonu: Yaşlı algısı üzerinden değerlendirmeler. Insan ve Toplum Dergisi, 3(5), 5-35.

Tiyek, R., Yertüm, U. (2016). Güney Avrupa refah rejimi bağlamında Türkiye: Bir değerlendirme. Kırklareli Üniversitesi İktisadi ve İdari Bilimler Fakültesi Dergisi, 5(1), $26-51$.

Tyler, T. R. (2006). Psychological perspectives on legitimacy and legitimation. Annual Review of Psychology, 57, 375-400.

Uslaner, E. M. (2002). The Moral Foundations of Trust. Cambridge University Press.

Uslaner, E. M. (2003). Trust, democracy, and governance: Can government policies influence generalized trust? In M. Hooghe \& S. Dietlind (Der.), Generating social capital: Civil society and institutions in comparative perspective (ss. 171-191). New York, NY: Palgrave Macmillan.

van Oorschot, W., Arts, W. (2005). The social capital of European welfare states: the Crowding-out hypothesis revisited. The Journal of European Social Policy, 15(1), 5-26. 
van Oorschot, W., Arts, W., Halman, L. (2005). Welfare state effects on social capital and informal solidarity in the European Union: Evidence from the 1999/2000 European values study. Policy \& Politics, 33(1), 33-54.

Wolfe, A. (1989). Whose keeper? Social science and moral obligation. Berkeley: University of California Press.

Yuksek, D. A. (2017). Moral destabilization of revivification: The trend of religion-based social capital following 9/11. Comparative Sociology, 16(6), 687-715.

Yuksek, D. A., Solakoglu, O. (2019). Individual attitudes toward the welfare state: A test of the 'crowding out hypothesis' across European countries. Comparative Sociology, 18(2), 117-147. 